\title{
Geology of the Elephanta Island fault zone, western Indian rifted margin, and its significance for understanding the Panvel flexure
}

\author{
Hrishikesh Samant ${ }^{1}$, Ashwin Pundalik ${ }^{1}$, Joseph D'souza ${ }^{2}$, Hetu Sheth ${ }^{2, *}$, \\ Keegan Carmo Lobo ${ }^{1}, \mathrm{Kyle}^{\mathrm{D}}$ 'souza $^{1}$ and Vanit Patel ${ }^{2}$ \\ ${ }^{1}$ Department of Geology, St. Xavier's College, Mumbai 400 001, India. \\ ${ }^{2}$ Department of Earth Sciences, Indian Institute of Technology Bombay, Powai, Mumbai 400 076, India. \\ ${ }^{*}$ Corresponding author. e-mail: hcsheth@iitb.ac.in
}

The Panvel flexure is a 150-km long tectonic structure, comprising prominently seaward-dipping Deccan flood basalts, on the western Indian rifted margin. Given the active tectonic faulting beneath the Panvel flexure zone inferred from microseismicity, better structural understanding of the region is needed. The geology of Elephanta Island in the Mumbai harbour, famous for the ca. mid-6th century A.D. Hindu rock-cut caves in Deccan basalt (a UNESCO World Heritage site) is poorly known. We describe a previously unreported but well-exposed fault zone on Elephanta Island, consisting of two large faults dipping steeply east-southeast and producing easterly downthrows. Well-developed slickensides and structural measurements indicate oblique slip on both faults. The Elephanta Island fault zone may be the northern extension of the Alibag-Uran fault zone previously described. This and two other known regional faults (Nhava-Sheva and Belpada faults) indicate a progressively eastward step-faulted structure of the Panvel flexure, with the important result that the individual movements were not simply downdip but also oblique-slip and locally even rotational (as at Uran). An interesting problem is the normal faulting, block tectonics and rifting of this region of the crust for which seismological data indicate a normal thickness (up to $41.3 \mathrm{~km}$ ). A model of asymmetric rifting by simple shear may explain this observation and the consistently landward dips of the rifted margin faults.

\section{Introduction}

Many continental flood basalt (CFB) provinces, located on rifted continental margins, display monoclinal flexures with prominent dips towards the newly formed ocean basin. Well-known examples are in the CFB provinces of the Karoo (Lebombo monocline), the Parana (Torres flexure), East Greenland, and the Deccan (Panvel flexure) (e.g., Nielsen and Brooks 1981; Sheth 1998; Klausen 2009). These flexures have been ascribed to folding or monoclinal bending (e.g., Blanford 1867; Wynne 1886; Wager and Deer 1938; Auden 1949; Faller and Soper 1979; Myers 1980), extensional faulting with block rotations (e.g., Nielsen and Brooks 1981; Dessai and Bertrand 1995), and reverse drag on offshore listric master faults, with attendant faulting (Sheth 1998).

The western Indian rifted continental margin (figure 1) evolved during two major episodes of continental break-up and CFB volcanism, at $\sim 85 \mathrm{Ma}$ between India and Madagascar (Storey et al. 1995; Pande et al. 2001) and at $~ 63$ Ma between India and Seychelles (Collier et al. 2008; Bhattacharya and Yatheesh 2015). The Panvel flexure in the $\sim 65$ Ma Deccan flood basalts runs along the

Keywords. Flood volcanism; Deccan traps; Panvel flexure; Mumbai; Elephanta Island; faulting. 


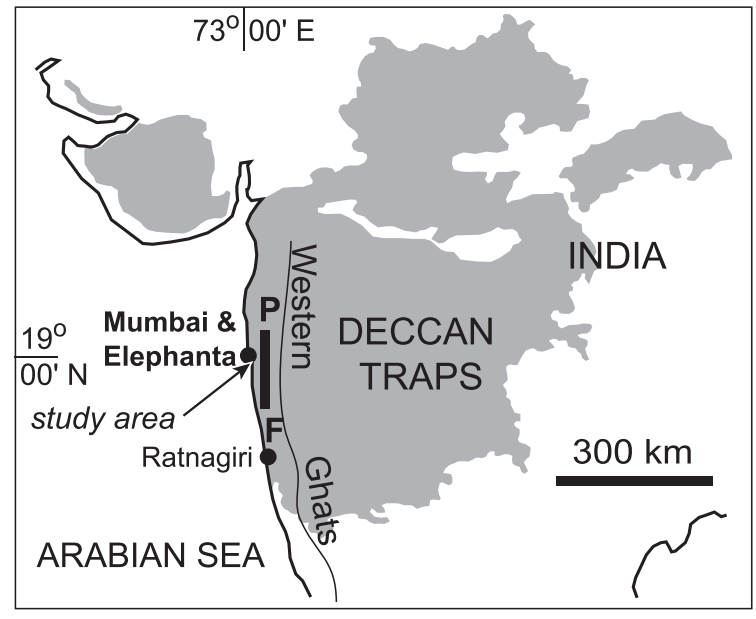

Figure 1. Map of India and the Deccan Traps (grey), showing the Western Ghats escarpment and the locations of Mumbai and Ratnagiri areas, discussed in the text. Bold line indicated by $\mathrm{PF}$ is the Panvel flexure, exposed on the Konkan Plain west of the escarpment.
NNW-SSE-trending western Indian rifted margin for $>150 \mathrm{~km}$, and has a width of $\sim 30 \mathrm{~km}$ (figure 1). Here we describe the geology of a fault zone in the Deccan basalts of Elephanta Island near Mumbai, in the Panvel flexure zone (figure 2). Unambiguous identification of faults in the Deccan flood basalts has been difficult because of the monotonous appearance of many basaltic sequences and the lack of marker horizons within them. The Elephanta Island fault zone is unreported in the existing literature, but it is well exposed, and provides valuable insights into the structure and tectonics of the Panvel flexure zone.

\section{Regional and local geology}

Mumbai, originally a group of several islands, is unusual in the Deccan CFB province due to its Danian-age (post-Cretaceous/Palaeogene boundary)

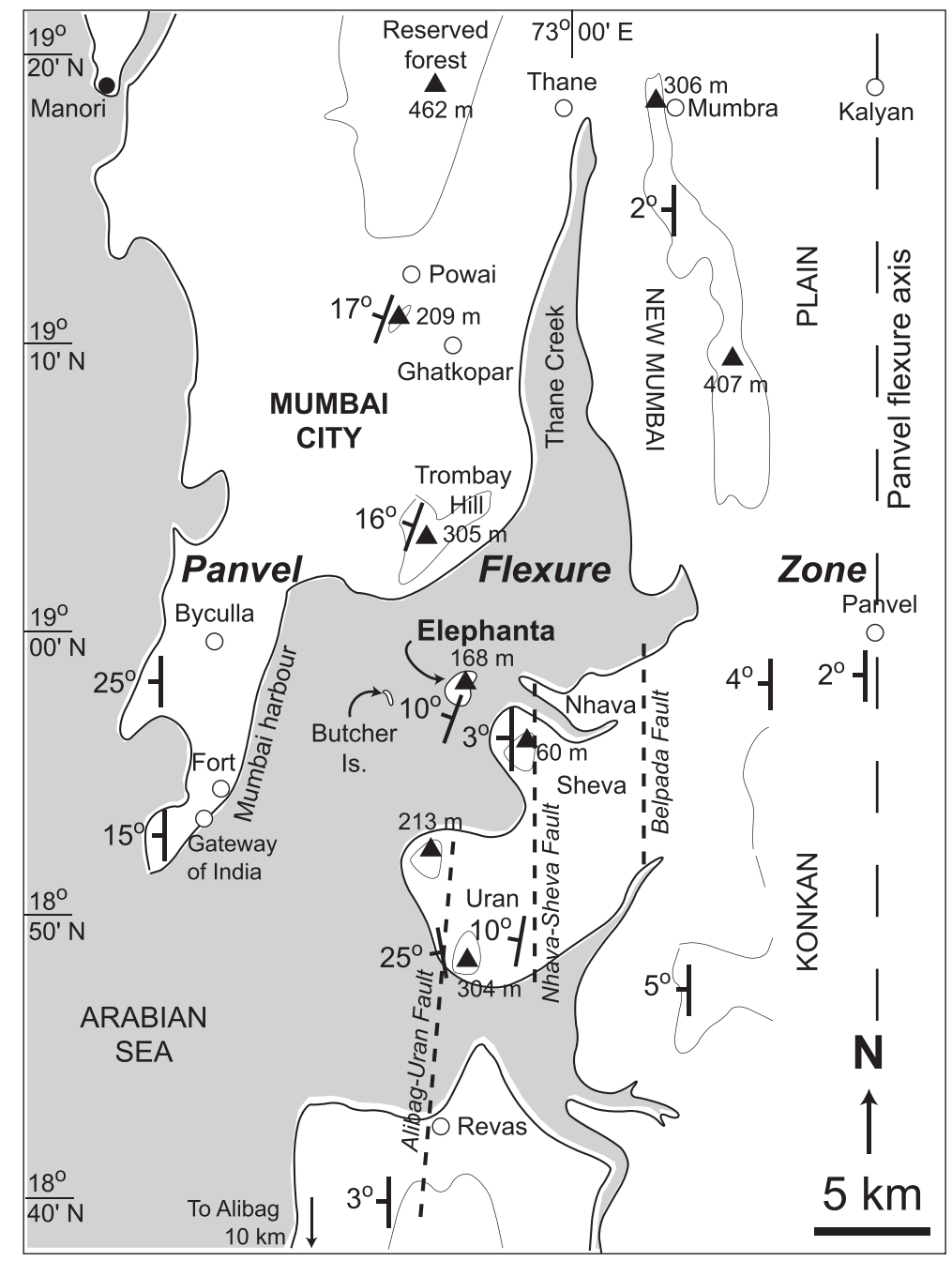

Figure 2. Map of Mumbai and the surrounding region, showing the major geographic, geological and structural features, and localities mentioned in the text (based on Dessai and Bertrand 1995; Sheth 1998). Hilly areas are shown by grey outlines, and elevations (in meters above sea level) by black triangles. 
magmatism, of varied composition and style. It shows lava flows of tholeiites, pillow basalts and spilites, hyaloclastites and rhyolites, with inter-trappean sediments and pyroclastic deposits, trachyte intrusions, and many dykes of varied compositions (e.g., Sukheswala and Poldervaart 1958; Sethna 1981, 1999; Cripps et al. 2005; Zellmer et al. 2012; Sheth et al. 2014). The entire sequence is affected by the Panvel flexure and has acquired prominent (typically $17^{\circ}$ ) seaward dips (figure 2 ). Hooper et al. (2010) argued that the Panvel flexure was formed at 65-64 Ma, soon after the Deccan eruptions, whereas Sheth and Pande (2014) concluded that the Panvel flexure postdates the Dongri rhyolite flow in northwestern Mumbai, dated by them at $62.6 \pm 0.6 \mathrm{Ma}$ and $62.9 \pm 0.2 \mathrm{Ma}$ $(2 \sigma)\left({ }^{40} \mathrm{Ar} /{ }^{39} \mathrm{Ar}\right.$ ages, relative to monitor MMhb-1 age of $523.1 \pm 2.6 \mathrm{Ma})$. The Deccan lavas to the east of Mumbai, in the New Mumbai and Nhava-ShevaUran areas of the Indian mainland, are also affected by the Panvel flexure, though their westerly dips are more gentle $\left(2-5^{\circ}\right)$ (figure 2$)$. The axis of the Panvel flexure passes through Panvel and Kalyan (figure 2), and further east the lavas are horizontal.

The island of Elephanta in the Mumbai harbour (rising $168 \mathrm{~m}$ above sea level and covered in large part in dense jungle, figure 3a) is little described in the geological literature. However, it is well known for the ca. mid-6th century AD Hindu rock-cut caves, a UNESCO World Heritage Site since 1987. The Deccan basalt lava flows of the island dip westnorthwest by $\sim 10^{\circ}$ (Dessai and Bertrand 1995 and our field data). The southeastern part of the island (figure $3 \mathrm{~b}$ ) exposes a thick $(>40 \mathrm{~m}$ ) lava flow of rubbly pahoehoe (Duraiswami et al. 2008; Sheth et al. 2011, 2017) with thick flow-top breccia and fans of columnar joints. This flow was quarried during the early to mid-seventies to provide construction material for the then upcoming major port of Nhava-Sheva, $1 \mathrm{~km}$ east of the island (figure 3a), but quarrying was stopped in a few years as it was found detrimental to the historical monument. Observations on the fault zone that we describe here can be made in and around the abandoned quarry (figure $3 \mathrm{~b}$ ).

\section{The Elephanta Island fault zone: Field observations}

The Elephanta Island fault zone consists of two distinct faults $\sim 70 \mathrm{~m}$ apart. The inner (western) fault (figure $4 \mathrm{a}, \mathrm{b}$ ) is best observed at the southwestern top edge of the quarry. It has an overall $\mathrm{N} 25^{\circ} \mathrm{E}$ trend, and a steep dip of $65^{\circ}$ due southeast (figure 4a). It is marked by a spectacular development of slickensides, filled by fine-grained white calcite and zeolites (slickenzones, Ragan
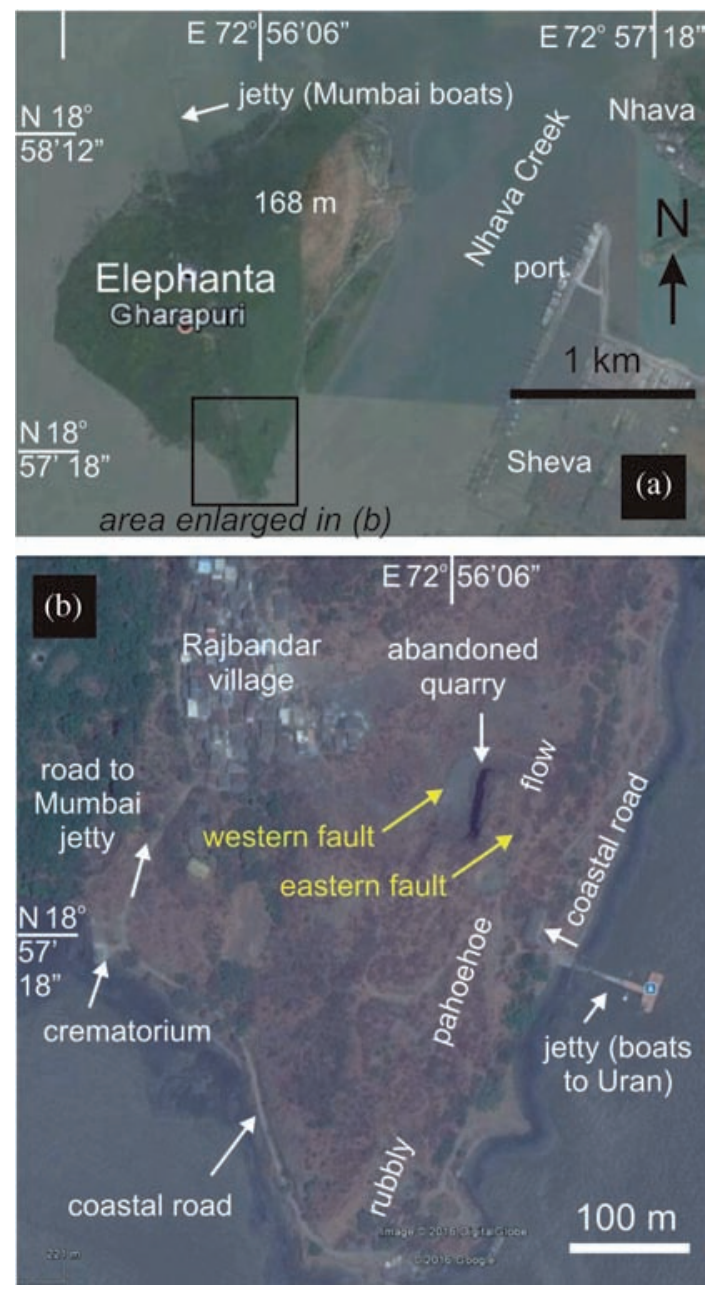

Figure 3. (a) Google Earth image of Elephanta Island in the Mumbai harbour, with parts of Nhava-Sheva port immediately to the east and on the Indian mainland. Box with black boundary shows the area of present study, enlarged in panel (b), where the locations of the faults studied in this paper and other features are marked.

2009). The slickensided surface is well exposed for a depth of $\sim 10 \mathrm{~m}$ at the top of the quarry (figure $4 \mathrm{~b}$ ), below which it stands largely destroyed by the quarrying. The slickenlines are steeply inclined towards south-southwest on the fault surface (figures 4b, 5a). The slickenlines are smooth to the touch in the downward direction and rough in the upward direction. This implies that the missing block (the eastern block now removed by quarrying) moved down relative to the block west of the fault and forming the quarry face (Doblas 1998; Argles 2010). The amount of downthrow is not determinable, and probably only a few meters, as the quarry's eastern inner wall (seen in shadow in figure 4a) also exposes the same rubbly pahoehoe flow. Fractures striking $\mathrm{N} 20^{\circ} \mathrm{E}$, subparallel to the fault, have formed in the basalt adjacent to the fault and are filled by thin veins of calcite and zeolites 


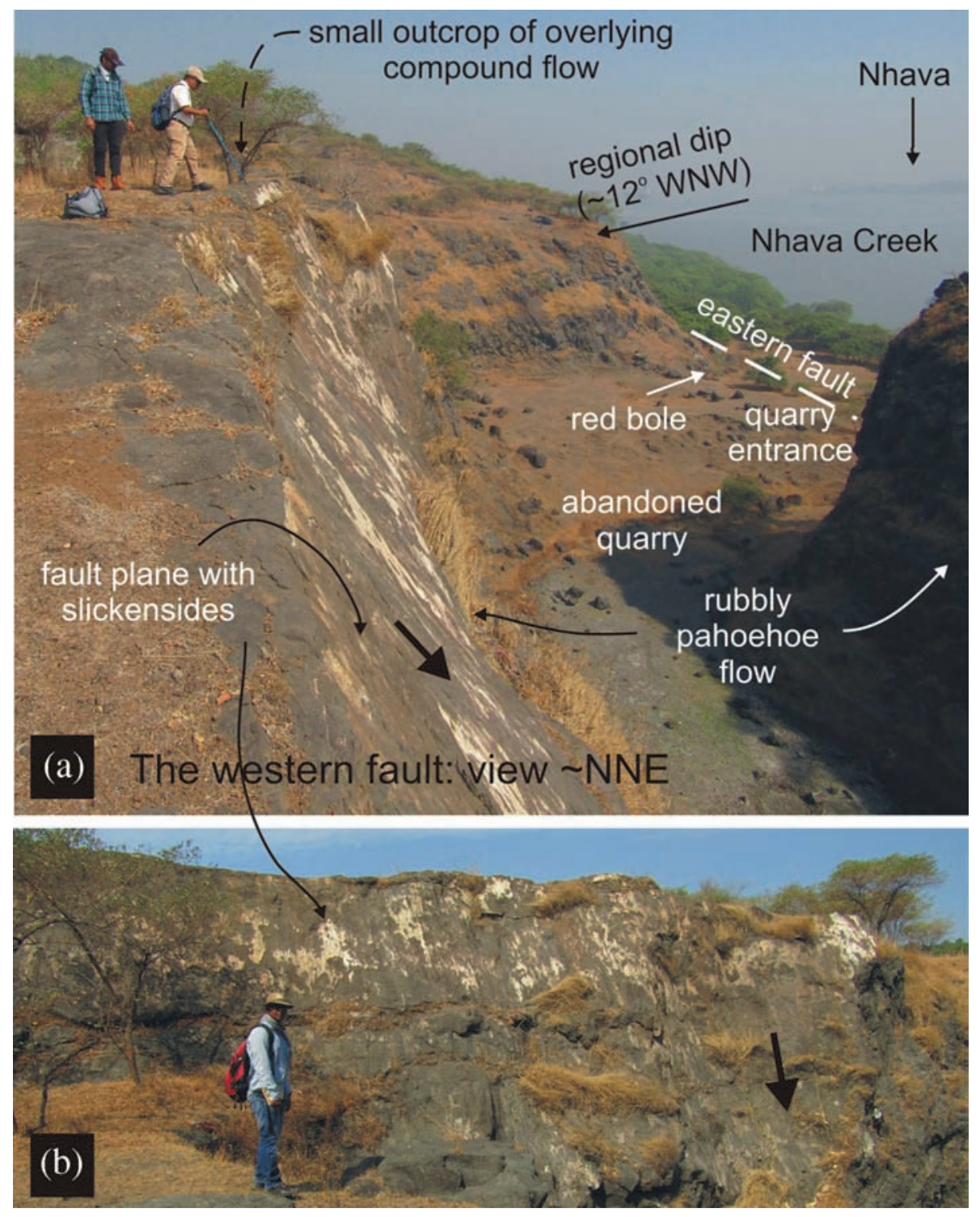

Figure 4. (a, b) Two views of the inner (western) fault in the rubbly pahoehoe flow, in the southeastern part of Elephanta Island. Geologists provide a scale. Fault strikes N25 E and dips $65^{\circ}$ due SE. White linear patches on the fault surface are due to secondary mineralization. Thick black arrows indicate the movement direction of the missing block. The quarry floor is $\sim 35 \mathrm{~m}$ below the top edge with the geologists. The location of the red bole at the entrance of the quarry, and of the outer fault affecting it, are also shown in (a).

(figure 5b). A large vug, containing centimetersize crystals of calcite and smaller crystals of stilbite (figure 5c), is also seen in the fault.

The outer (eastern) fault is seen affecting the rubbly pahoehoe flow on a dirt path adjacent to the coastal road (figure 3b). The fault surface is again easily identifiable because of well-developed slickenlines (figure $6 \mathrm{a}-\mathrm{d}$ ). However, unlike the western fault which can be visually continuously traced for $\sim 150 \mathrm{~m}$, most of the eastern fault has been destroyed by quarrying and it is only exposed discontinuously. At one place, a large landslide has produced much bouldery rubble including boulders with slickensides (figure 7 ). Unlike the $\mathrm{N} 25^{\circ} \mathrm{E}$ strike of the western fault, the eastern fault has an overall strike of $\mathrm{N} 36^{\circ} \mathrm{E}$ (average of 32 readings ranging between $\mathrm{N} 10^{\circ} \mathrm{E}$ and $\mathrm{N} 54^{\circ} \mathrm{E}$, table 1), and it dips very steeply (average $73^{\circ}$ ) due southeast. The slickenlines have a rake of $\sim 68^{\circ}$ on the western fault, while the rake measured on the eastern fault is $\sim 55^{\circ}$, varying somewhat along the exposure but always due southwest (figure $6 \mathrm{a}-\mathrm{d}$ ). This means that the movement along the outer fault was also oblique-slip. Similar to the western fault, the slickensided faces are always smooth to the touch downwards and rough upwards, implying that the missing (eastern) block (on which we stood) has moved relatively down. 

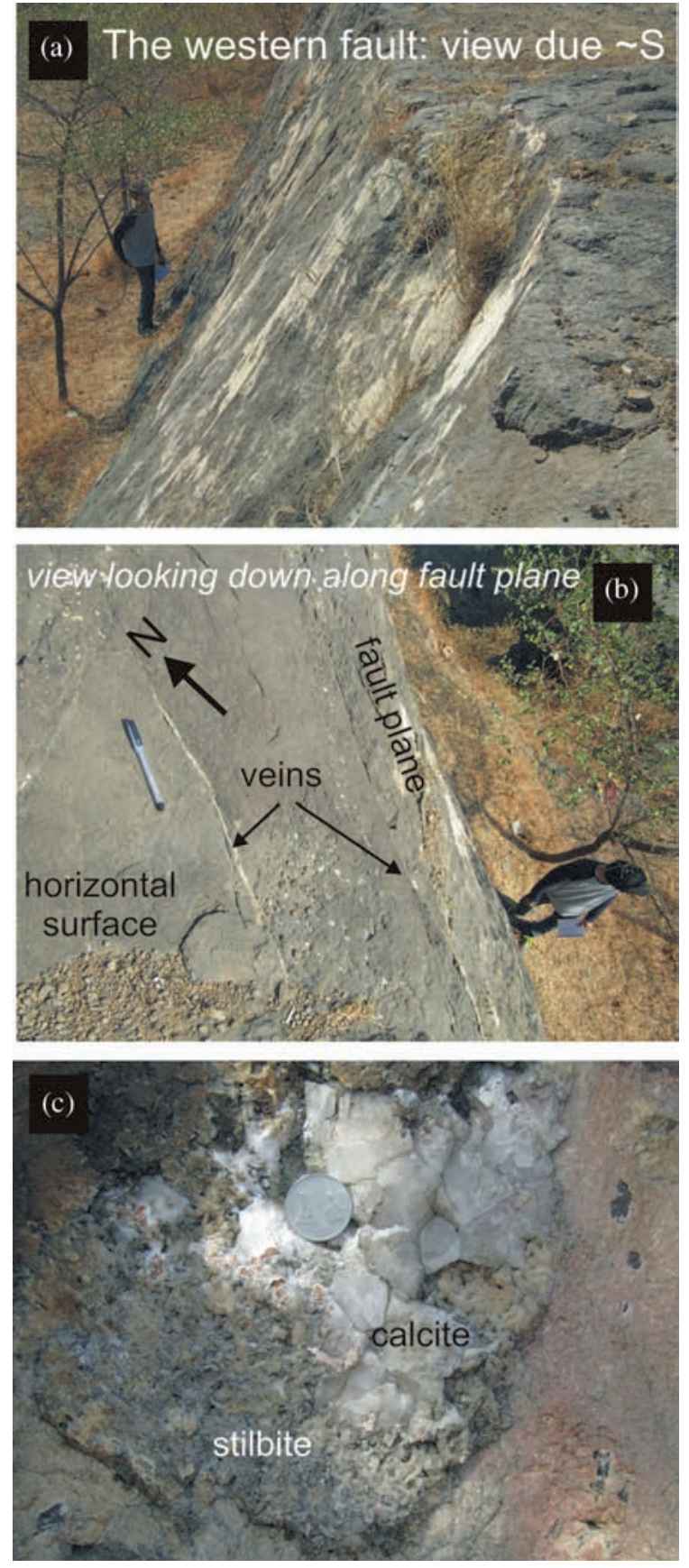

Figure 5. (a) View of the western fault looking roughly due south along the fault surface. White linear patches are secondary mineralization. (b) Secondary mineral veins adjacent to and parallel with the fault surface; view looking down along the fault from the cliff edge. (c) A large mineralized pocket with well-developed calcite and stilbite, on the fault surface shown in (a). Coin for scale is $2.5 \mathrm{~cm}$ in diameter.

A few tens of meters to the north of the outcrops shown in figure $6(\mathrm{a}-\mathrm{d})$ is the wide entrance to the quarry. A small exposure of red bole occurs below the rubbly pahoehoe flow at the northern end of this entrance (figure 4a). This red bole may represent the chilled glassy base of the rubbly pahoehoe flow, subsequently heavily altered (see Duraiswami et al. 2008). Fragments of the red bole also show the development of slickensides (figure 6e). The outer fault therefore passes through here (see figure 4a), and is untraceable further north along the coastal road owing to dense vegetation and lack of outcrops. The amount of easterly downthrow along the outer fault is again undeterminable, as the red bole (a potential marker horizon) is not exposed anywhere within or outside the quarry. Both faults may originally have been much longer than their current trace length of $\sim 150 \mathrm{~m}$, though they are now destroyed by quarrying or hidden by the jungle. A map of the two faults and a corresponding block diagram showing the topographic and structural features are shown in figure $8(\mathrm{a}, \mathrm{b})$.

\section{Structural measurements and data analysis}

We carried out structural measurements in the fault zone with the objective to determine the net slip directions on both faults. Initially, the attitude of the western and the eastern faults was recorded at different locations. The rake of slickenlines was recorded at a $1 \mathrm{~m}$ grid interval on both faults (table 1) and the lineations were plotted and contoured with a $15 \%$ contour interval on Lambert's equal area projection. Contour diagrams of slickenlines for the western and eastern faults (figure 9a, b) show presence of maxima of $>45 \%$ towards $\mathrm{N} 158^{\circ}$ and $\mathrm{N} 195^{\circ}$, respectively.

The rake measurements were used to calculate the plunge of the slickenlines using the stereonet, and rose diagrams showing the plunge of these slickenlines on an equal-area projection were prepared for both faults (figure 9c, d). It is observed that the western fault has a dominant mode of $30 \%$ towards $\mathrm{N} 157^{\circ}$ and $\mathrm{N} 162^{\circ}$ and a mode of $24 \%$ towards $\mathrm{N} 172^{\circ}$. The eastern fault has a dominant mode of $43 \%$ towards $\mathrm{N} 192^{\circ}$ with subordinate modes of $28 \%$ and $10 \%$ towards $\mathrm{N} 197^{\circ}$ and $\mathrm{N} 152^{\circ}$, respectively.

Fossen (2010) has given a geometrical procedure to calculate orientations of the stress axes from fault slip data using the tangent lineation diagram. The plane containing the lineation on the fault plane and the pole to the fault plane is defined by him as the movement plane (M-plane). The M-plane contains the maximum and minimum principal stress axes. The tangent lineation for a known fault plane is found by plotting the M-plane and the fault plane on a stereonet, and the sense of movement is given by the orientation of the arrow tangential to the M-plane, at the pole to the fault plane. The principal stress directions were determined using this method, along with the movement of the footwall relative to the hanging 

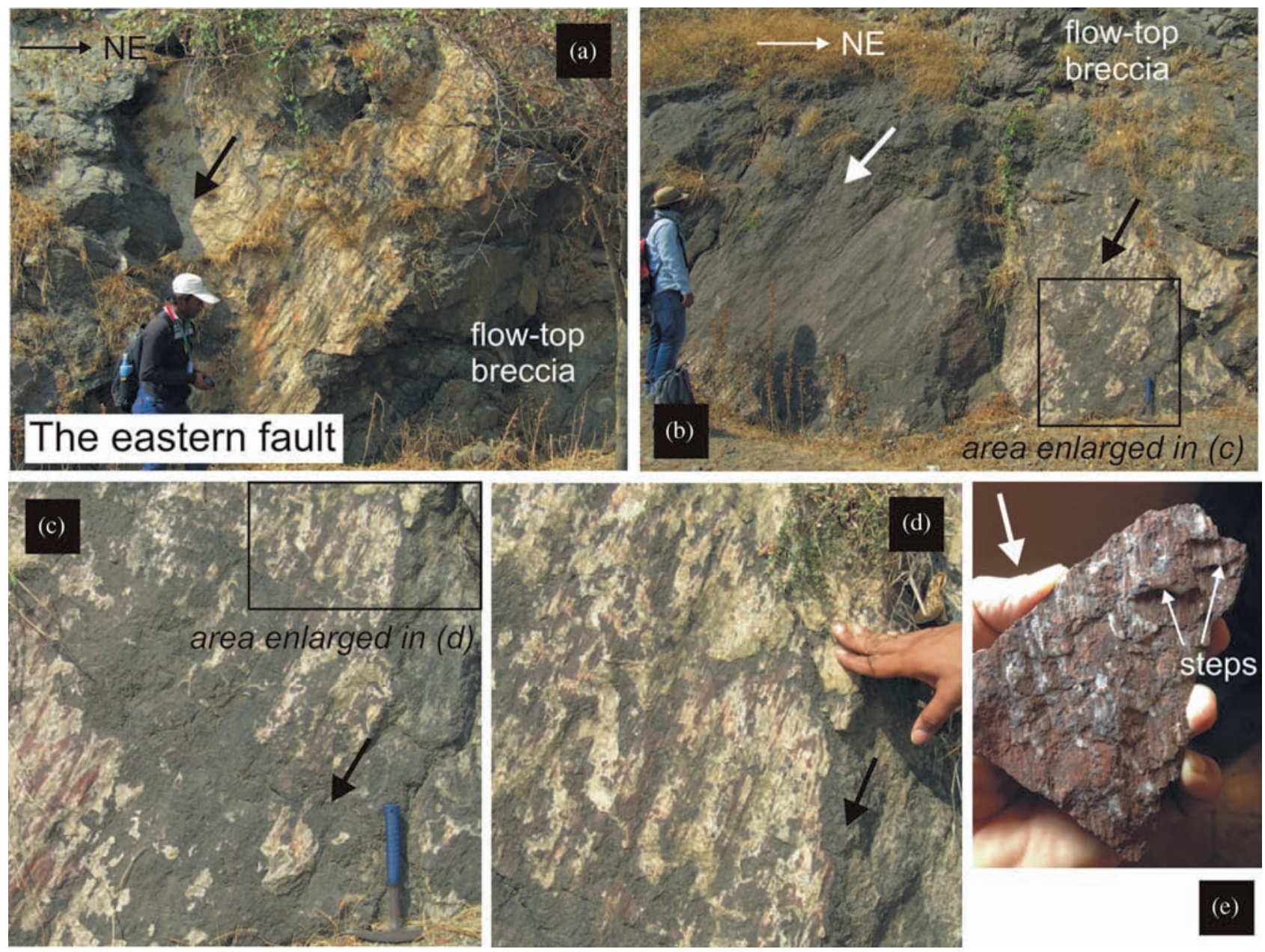

Figure 6. The outer fault striking $\mathrm{N} 55^{\circ} \mathrm{E}$ and dipping $80^{\circ} \mathrm{SE}$ (locally) and with well-formed, mineralized or barren slickensides. Geologists (a, b), hammer (c) and hand (d) provide a scale. Panel (e) shows a hand-held red bole specimen with slickenlines. Small white arrows indicate two of the steps on the slickenlines. Thick black or white arrows in all panels indicate the direction of movement of the missing block.

wall (figure 10a, b). Due to the frictional resistance offered by the internal properties of various solids, the angle of internal friction $(\varphi)$ is a major factor determining the angle at which failure takes place in the rock relative to the orientations of the stress axes (Ragan 2009). In extensional stress regimes, where the maximum principal stress $\left(\sigma_{1}\right)$ is vertical, a set of two fractures may develop at an angle $\theta$ from $\sigma_{1}$. As explained by Coulomb's theory of faulting, and with an angle of internal friction of $30^{\circ}$ for most rocks, the angle $\theta= \pm 45-(\varphi / 2)$, i.e., $30^{\circ}$ on either side of $\sigma_{1}$ (Fossen 2010). Therefore, $\sigma_{1}$ is plotted on the M-plane at an angle of $30^{\circ}$ from the lineation. The minimum principal stress $\sigma_{3}$ is plotted on the M-plane at an angle of $90^{\circ}$ from $\sigma_{1}$. The intermediate principal stress $\sigma_{2}$ can therefore be plotted as the pole to the M-plane and it will always lie on the fault plane itself. This method is used for rocks without structural fabric or pre-faulting deformation. Since the rubbly pahoehoe flow hosting the faults does not show signatures of any prior deformational events, we used Fossen's (2010) method to estimate the palaeostress conditions that generated these faults. The western fault indicates a steeply plunging $\sigma_{1}$ $\left(70^{\circ} / 226^{\circ}\right)$, a gently plunging $\sigma_{2}\left(20^{\circ} / 035^{\circ}\right)$, and a nearly horizontal $\sigma_{3}\left(03^{\circ} / 126^{\circ}\right)$ (figure 10a). The eastern fault indicates moderately plunging $\sigma_{1}$ $\left(55^{\circ} / 245^{\circ}\right)$ and $\sigma_{2}\left(32^{\circ} / 047^{\circ}\right)$ and a gently plunging $\sigma_{3}\left(08^{\circ} / 142^{\circ}\right)$ (figure $10 \mathrm{~b}$ ). The orientations of the stress axes for both the faults are thus similar.

The palaeostress method mentioned above relates fault slip and stress through the WallaceBott assumption which states that the slip directions are not affected by pore fluid pressures (Yamaji 2007), and thus oversimplifies the crustal condition (Fossen 2010). A kinematic analysis of the fault slip data, which relies on palaeostrain analysis rather than stress, was therefore carried out (Fossen 2010). In this method, the P- and T-axes are symmetry axes for contractional and extensional quadrants, which are separated 


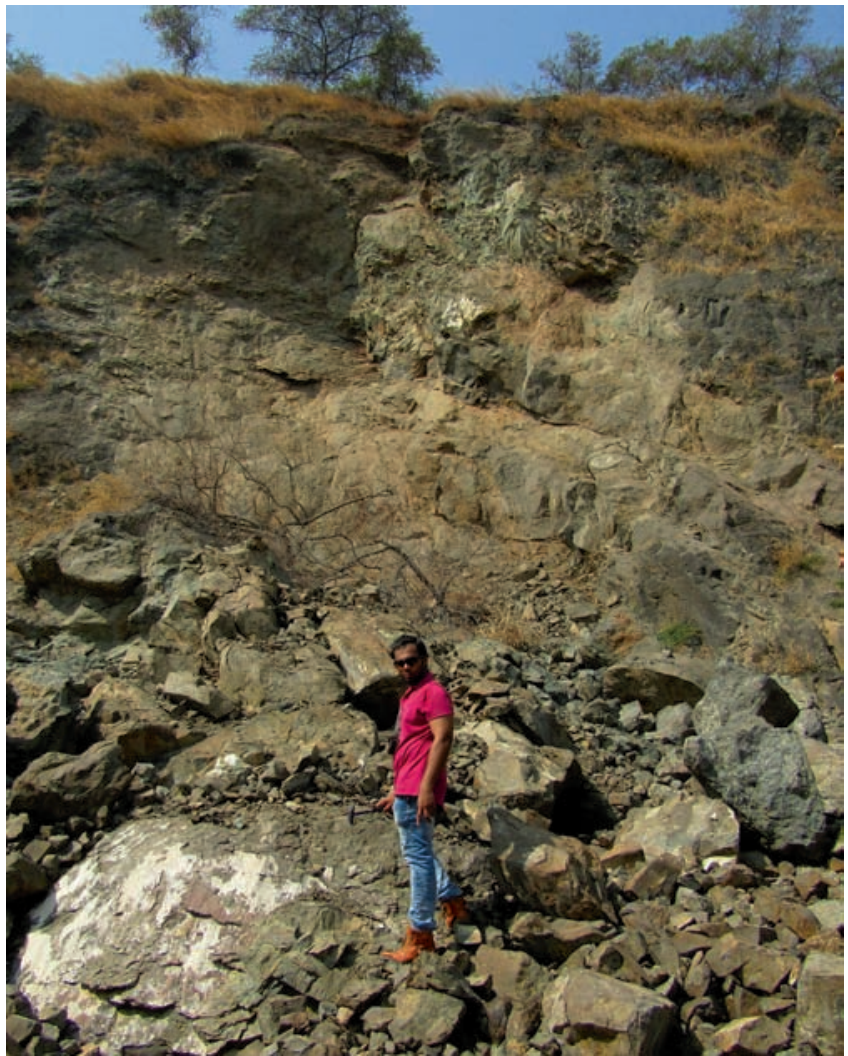

Figure 7. Landslide rubble and cliff face in the rubbly pahoehoe flow over the eastern fault. Large block in lower left corner shows a slickenside, and a boulder of flow-top breccia is seen near the lower right edge of the photo. A columnar rosette is seen near the top of the cliff.

by the fault planes and their complementary shear planes (at $90^{\circ}$ to the former). The P- and T-axes are plotted in the middle of these quadrants at an angle of $45^{\circ}$ on either side of the lineations (figure 10c, d). The orientations of the palaeostrain axes were measured by plotting the maximum and minimum directions of extension, $\mathrm{X}$ and $\mathrm{Z}$, in the middle of the $\mathrm{T}$ - and P-fields, respectively. The intermediate strain axis, $\mathrm{Y}$, was plotted at the intersection of the fault- and complementary planes (Fossen 2010) (figure 10e, f). The magnitude of the palaeostrain is not determined since the displacement along the faults could not be measured. The strain axes were determined using Bingham Analysis (Cheeney 1983) which gives objective directional maxima for the compression and extension axes for a fault array (Marrett and Allmendinger 1990). The obtained orientations of the principal strain axes for the western fault are $\mathrm{X}\left(08^{\circ} / 131^{\circ}\right)$, Y $\left(31^{\circ} / 036^{\circ}\right)$ and $\mathrm{Z}\left(58^{\circ} / 234^{\circ}\right)$ (figure $10 \mathrm{e}$ ), while those for the eastern fault are $\mathrm{X}\left(20^{\circ} / 152^{\circ}\right), \mathrm{Y}\left(34^{\circ} / 048^{\circ}\right)$ and $\mathrm{Z}$ $\left(49^{\circ} / 267^{\circ}\right)$ (figure 10f). According to Fossen (2010), $\mathrm{Z}$ must lie in the $\mathrm{P}$-field while $\mathrm{X}$ should lie in the T-field. Since the rubbly pahoehoe flow lacks structural fabric, layering or rheological variations, it can be considered homogeneous and mechanically isotropic. Hence the obtained orientations of the stress axes (figure 10a, b) and the strain axes (figure 10e, f) are consistent with each other for each fault, and the strain axes are indicative of instantaneous stretching directions.

\section{Discussion}

\subsection{Net slip directions on the Elephanta Island faults}

As noted, the slickenlines on the two faults are not oriented downdip, but are steeply to moderately inclined towards south-southwest or southwest $\left(40^{\circ}-75^{\circ}\right)$, suggesting oblique slip on both faults. The western fault strikes $\mathrm{N} 25^{\circ} \mathrm{E}$, and the net slip direction on this fault determined from the structural measurements is towards $\mathrm{N} 157^{\circ}$ (figure 9c). This confirms the oblique nature of the slip on the western fault. The eastern fault strikes $\mathrm{N} 36^{\circ} \mathrm{E}$, and the net slip direction on the fault, from the structural measurements, is towards $\mathrm{N}_{192}{ }^{\circ}$ (figure 9d). This confirms that neither of the faults has purely downdip movement, and both had significantly oblique-slip movements. The directions of maximum shear stress on the fault planes are indicated by the slickenlines developed, and movement along fault planes is only possible when the shear stress is greater than the frictional resistance offered by the fault planes.

Slickenstructures (Fleuty 1974, 1987; Ragan 2009) are produced by abrasional or depositional processes acting during slip and have been used to deduce the sense of shear on fault surfaces (Angelier 1994; Doblas 1998; Fossen 2010). According to Groshong (2006), the orientation of slickenlines indicates the slip direction of fault. Doblas (1998) has divided slickensides into eleven major groups based on their morphology, namely ' $\mathrm{V}$ ' or crescentic markings, steps, fractures, trains of inclined planar structures, trailed minerals, asymmetric elevations, deformed elements, mineralogical and crystallographic orientations, asymmetric cavities, asymmetric folds and asymmetric plan view features. The slickensides on the Elephanta Island faults show the presence of steps facing towards SSE and SSW respectively, i.e., in the direction of net slip vector. Such steps represent extension fractures, which are commonly mineralized (Petit and Laville 1987; Doblas et al. 1995; Doblas 1998; Fossen 2010). On the slickensided surfaces of both the faults, thin fibrous coatings showing stretched slickenfibers were seen. This type of coating was termed slickenzones by Ragan (2009), who considered it deposited from aqueous solutions during sliding. The orientation of 
Table 1. Structural measurements of slickenlines on the western and eastern fault planes, Elephanta Island.

\begin{tabular}{|c|c|c|c|c|}
\hline \multirow[b]{2}{*}{ Sl. no. } & \multirow[b]{2}{*}{$\begin{array}{c}\text { Strike, dip } \\
\left({ }^{\circ}\right)\end{array}$} & \multicolumn{3}{|c|}{ Attitude of slickenlines } \\
\hline & & $\begin{array}{c}\text { Bearing } \\
\left({ }^{\circ}\right)\end{array}$ & $\begin{array}{c}\text { Plunge } \\
\left({ }^{\circ}\right)\end{array}$ & $\begin{array}{c}\text { Rake } \\
\left({ }^{\circ}\right)\end{array}$ \\
\hline \multicolumn{5}{|c|}{ Western fault } \\
\hline 1 & N029, 59 & N167 & 52 & 68 \\
\hline 2 & N010, 66 & N155 & 58 & 68 \\
\hline 3 & N021, 61 & N148 & 58 & 76 \\
\hline 4 & N013, 71 & N165 & 61 & 68 \\
\hline 5 & N016, 64 & N158 & 57 & 69 \\
\hline 6 & N015, 65 & N157 & 58 & 69 \\
\hline 7 & N016, 59 & N153 & 52 & 68 \\
\hline 8 & N015, 65 & N157 & 53 & 69 \\
\hline 9 & N020, 56 & N159 & 49 & 66 \\
\hline 10 & N019, 55 & N142 & 51 & 76 \\
\hline 11 & N010, 60 & N153 & 51 & 65 \\
\hline 12 & N010, 59 & N146 & 52 & 69 \\
\hline 13 & N029, 58 & N159 & 54 & 73 \\
\hline 14 & N013, 59 & N156 & 50 & 64 \\
\hline 15 & N011, 64 & N141 & 51 & 72 \\
\hline 16 & N020, 55 & N156 & 52 & 68 \\
\hline 17 & N011, 56 & N152 & 55 & 68 \\
\hline 18 & N025, 62 & N172 & 30 & 62 \\
\hline 19 & N022, 60 & N160 & 37 & 65 \\
\hline 20 & N018, 54 & N183 & 47 & 52 \\
\hline 21 & N010, 68 & N178 & 42 & 55 \\
\hline 22 & N008, 67 & N169 & 42 & 50 \\
\hline 23 & N022, 62 & N183 & 50 & 56 \\
\hline 24 & N013, 68 & N164 & 44 & 55 \\
\hline 25 & N025, 57 & N175 & 46 & 58 \\
\hline 26 & N016, 58 & N175 & 48 & 54 \\
\hline 27 & N008, 67 & N167 & 52 & 58 \\
\hline 28 & N025, 68 & N164 & 42 & 52 \\
\hline 29 & N014, 58 & N174 & 44 & 52 \\
\hline 30 & N016, 62 & N176 & 40 & 48 \\
\hline 31 & N015, 58 & N169 & 42 & 53 \\
\hline 32 & N020, 57 & N175 & 45 & 55 \\
\hline 33 & N019, 60 & N171 & 47 & 58 \\
\hline 34 & N011, 60 & N166 & 41 & 52 \\
\hline 35 & N018, 56 & N172 & 40 & 52 \\
\hline 36 & N010, 55 & N169 & 41 & 50 \\
\hline 37 & N012, 59 & N162 & 44 & 57 \\
\hline 38 & N006, 57 & N139 & 56 & 68 \\
\hline 39 & N006, 58 & N151 & 42 & 53 \\
\hline 40 & N015, 54 & N163 & 43 & 57 \\
\hline
\end{tabular}

Eastern fault

$\begin{array}{lllll}1 & \mathrm{~N} 021,82 & \mathrm{~N} 192 & 50 & 50 \\ 2 & \mathrm{~N} 022,89 & \mathrm{~N} 201 & 53 & 53 \\ 3 & \mathrm{~N} 023,82 & \mathrm{~N} 191 & 55 & 56 \\ 4 & \mathrm{~N} 010,78 & \mathrm{~N} 178 & 44 & 45 \\ 5 & \mathrm{~N} 029,79 & \mathrm{~N} 185 & 51 & 52 \\ 6 & \mathrm{~N} 043,62 & \mathrm{~N} 182 & 50 & 61 \\ 7 & \mathrm{~N} 039,74 & \mathrm{~N} 194 & 56 & 60 \\ 8 & \mathrm{~N} 046,74 & \mathrm{~N} 200 & 56 & 60 \\ 9 & \mathrm{~N} 037,80 & \mathrm{~N} 205 & 49 & 50 \\ 10 & \mathrm{~N} 042,76 & \mathrm{~N} 192 & 49 & 50\end{array}$

Table 1. (Continued.)

\begin{tabular}{lcccc}
\hline & & \multicolumn{3}{c}{ Attitude of slickenlines } \\
\cline { 3 - 5 } Sl. no. & Strike, dip & $\begin{array}{c}\text { Bearing } \\
\left({ }^{\circ}\right)\end{array}$ & $\begin{array}{c}\text { Plunge } \\
\left({ }^{\circ}\right)\end{array}$ & $\begin{array}{c}\text { Rake } \\
\left({ }^{\circ}\right)\end{array}$ \\
\hline 11 & N034, 75 & N194 & 52 & 55 \\
12 & N041, 76 & N200 & 54 & 56 \\
13 & N039, 69 & N195 & 46 & 50 \\
14 & N030, 78 & N199 & 42 & 43 \\
15 & N032, 69 & N191 & 41 & 45 \\
16 & N048, 69 & N196 & 54 & 60 \\
17 & N042, 68 & N200 & 42 & 46 \\
18 & N030,77 & N195 & 48 & 50 \\
19 & N029, 83 & N202 & 50 & 50 \\
20 & N026, 74 & N186 & 48 & 50 \\
21 & N031, 84 & N200 & 59 & 60 \\
22 & N046, 74 & N213 & 39 & 40 \\
23 & N040, 80 & N208 & 48 & 49 \\
24 & N054, 60 & N187 & 52 & 65 \\
25 & N038, 69 & N180 & 58 & 60 \\
26 & N036, 74 & N191 & 56 & 60 \\
27 & N049, 65 & N168 & 61 & 75 \\
28 & N043, 63 & N194 & 43 & 50 \\
29 & N049, 64 & N193 & 50 & 58 \\
30 & N043, 64 & N169 & 59 & 72 \\
31 & N030, 64 & N175 & 46 & 55 \\
32 & N043, 64 & N190 & 48 & 55 \\
\hline
\end{tabular}

slickenfibers in such coatings identifies the latest slip direction, or shear direction (Blekinsop 2002). According to Hobbs et al. (1976), the steps on slickensides normally face the direction of movement on the fault, but inverses have also been produced experimentally. Argles (2010) has stated that slickenfibers grow during the fault creep and in the direction of slip, while steps on the slickenfibers indicate the sense of motion of the fault, which is down the steps. In the Elephanta Island faults, clusters of undeformed zeolites and calcite across slickenlines were also seen. These are definitely post-slip and thus indicate at least two phases of mineralization along the fault planes.

To summarize, slickenstructures observed on the Elephanta Island faults are kinematic indicators signifying oblique-slip nature of the faults, with net slip vectors oriented towards SSE (for the western fault) and SSW (for the eastern fault). The obliqueslip nature of these faults is further supported by the southwesterly plunging maximum principal stress for both of them (figure 10a, b).

\subsection{Structural framework and age of the Elephanta Island and associated fault zones}

We have reported here, from the Deccan basalts of Elephanta Island, two well-exposed normal faults, with oblique slip and southeasterly downthrows. 
(a)
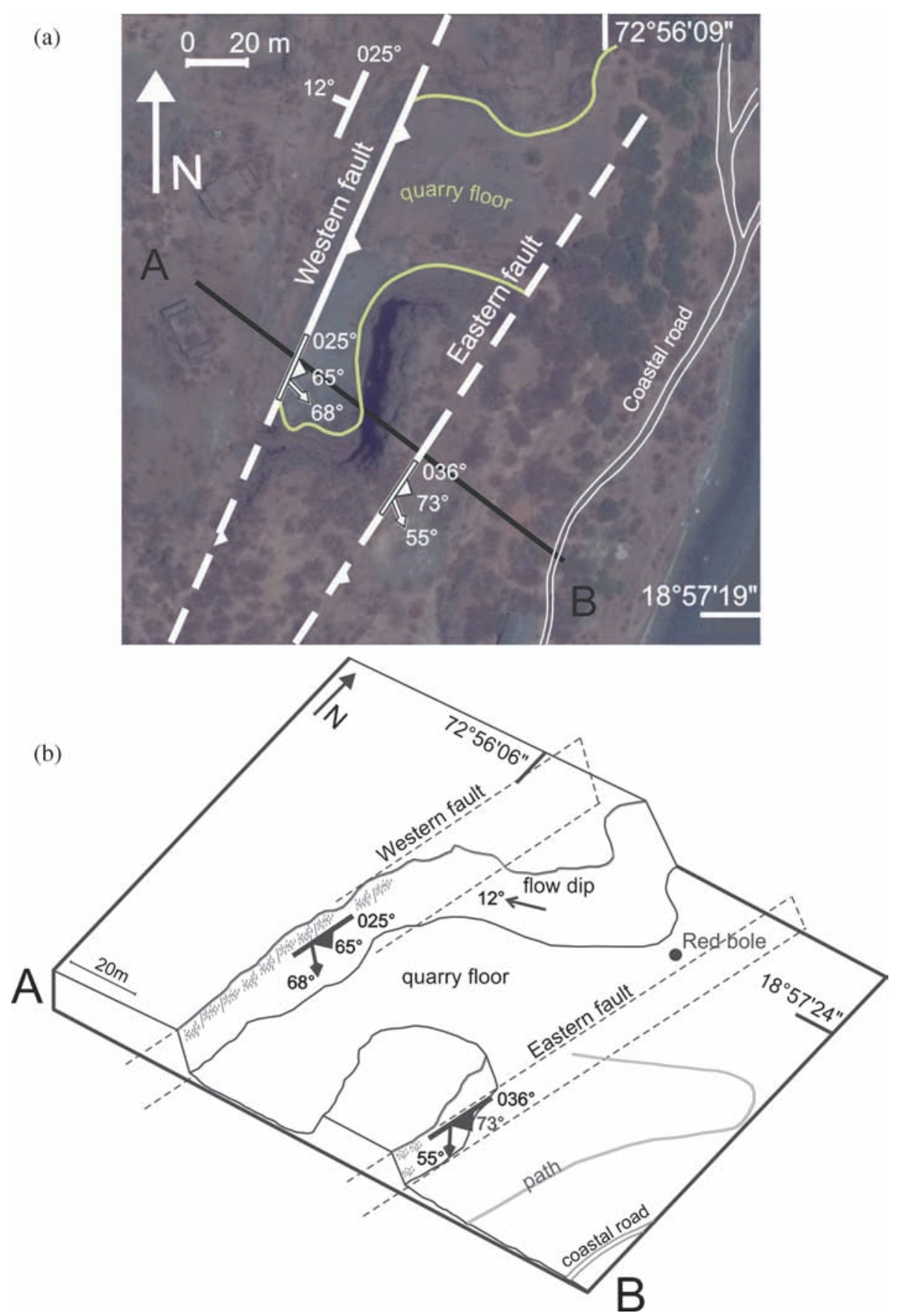

Figure 8. (a) Google Earth image of the area, including the abandoned quarry, where the faults described in the paper are best exposed. (b) Block diagram explaining the topographic and structural features of this area. The top of the western fault scarp stands $45 \mathrm{~m}$ above sea level and $\sim 35 \mathrm{~m}$ above the quarry floor.

These faults have not been reported in the previous literature. That they are indeed faults, and not merely fractures or joints, is indicated by well-developed slickensides.

A question is whether these faults are of Deccan age or formed much later. If the former, the faults would provide clues to the structure and tectonics of the Panvel flexure. Otherwise, they have no relationship with the Panvel flexure, and may be related to neotectonic activity along the western Indian rifted margin. There is geophysical and geological evidence for neotectonics along the margin and in the Panvel flexure zone in particular, covering the region shown in figure 2. Mohan et al. (2007) carried out microseismic studies in the Panvel flexure zone and reported that 158 earthquakes (with coda magnitude $M_{c}$ 1.0-3.6) including 41 events of magnitude $M_{c} \geq 2.5$ occurred along the flexure and adjacent areas during 1998-2005. Historical seismicity records from the year 1594 to 


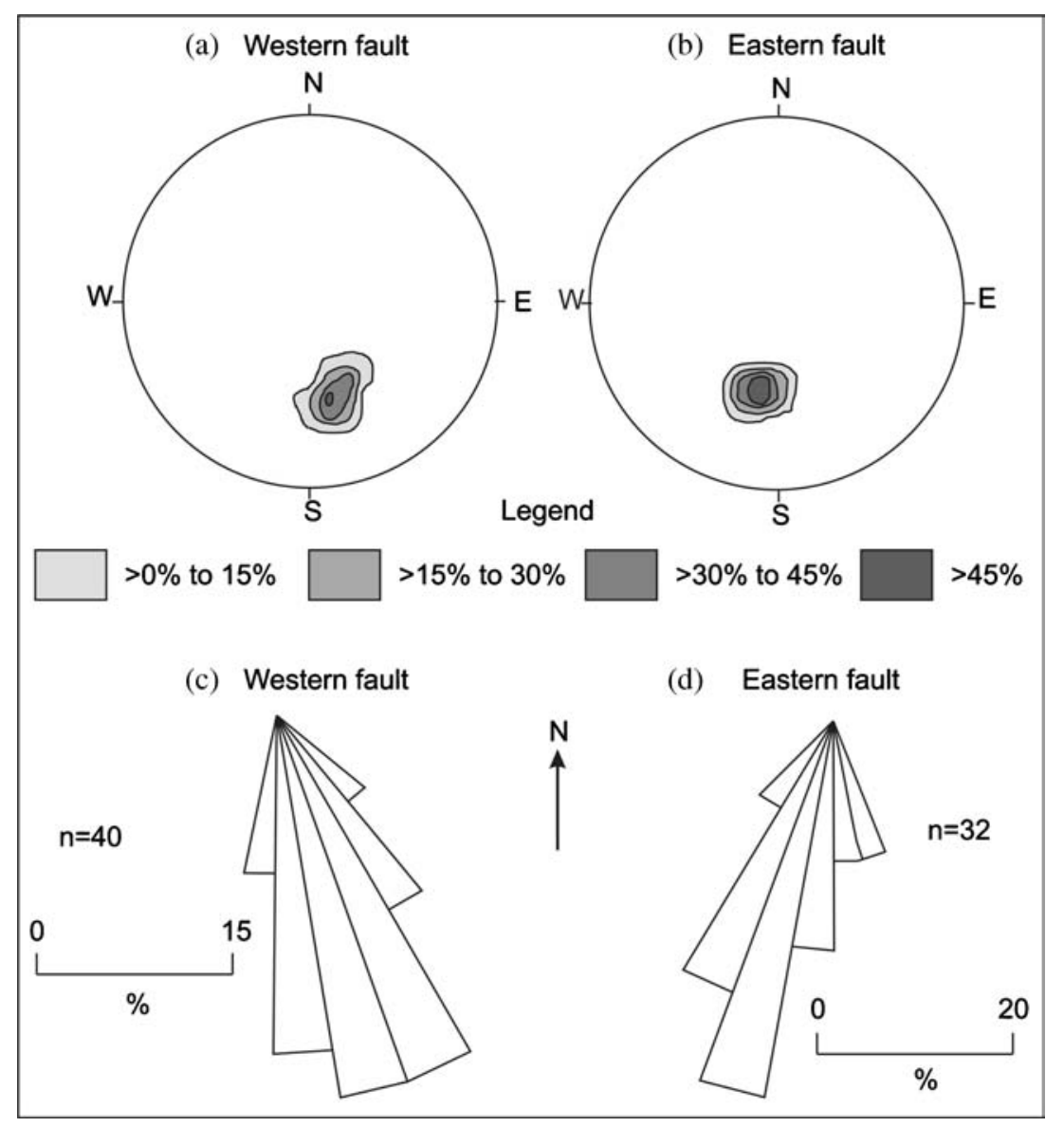

Figure 9. (a, b) Contour diagrams for slickenlines on Elephanta Island faults. (c, d) Rose diagrams of bearings of slickenlines for the Elephanta Island faults.

1967 (see their table 4) indicate about 24 moderate earthquakes of intensity $\geq I V$ in this region. Several such earthquakes have occurred near Uran, including possibly the 1618 Bombay earthquake of intensity IX (and equivalent magnitude 7). Mohan et al. (2007) grouped the microearthquake depths into near-surface $(<2 \mathrm{~km}$ and within the Deccan lava pile), shallow $(2-15 \mathrm{~km})$ and deep $(>15 \mathrm{~km})$, and considered the latter two as due to reactivation of basement faults. They also inferred block faulting of the region and active subsurface faulting under the Panvel flexure zone.

Kundu and Matam (2000) described geological evidences for neotectonic activity in the Deccan basalts of Ratnagiri area (figure 1), including very straight streams, rock fractures, and shearing and boudinage of quartz veins. They reported NNW-SSE-trending dip-slip faults with slickensides, and considered them possibly neotectonic. Widdowson and Mitchell (1999) argued for denudational isostasy in the Deccan Traps, meaning that erosional unroofing of the Deccan Traps leads to the upward propagation of basement fractures into the basaltic pile. Notably, the fabric of the Precambrian Dharwar basement south of the Deccan province is NNW-SSE to NW-SE, and the NNW-SSEtrending neotectonic faulting reported by Kundu and Matam (2000) may have this cause. The same mechanism, however, is unlikely for the Elephanta faults we have described, as these trend $\mathrm{N} 25^{\circ} \mathrm{E}$ and $\mathrm{N} 36^{\circ} \mathrm{E}$.

Misra et al. (2014) have identified $\sim \mathrm{N}-\mathrm{S}$-trending brittle shear zones and faults with slickensides in the Deccan basalts of the western Indian rifted margin. Samant (1997) previously showed centimeter-scale faults with slickensides, of the kind illustrated by Misra et al. (2014) and related by them to regional-scale, Deccan-age strike-slip tectonics. The Elephanta faults described here are much larger (figures 4,6) than these centimeterscale faults and are unlikely to be neotectonic. More importantly, the Elephanta Island fault zone is not an isolated one but part of a system of regional subparallel fault zones. Dessai and Bertrand (1995) have shown three parallel faults in the area south and east of Elephanta Island (figure 2). The westernmost is a $\mathrm{N} 35^{\circ} \mathrm{E}$-trending, $25 \mathrm{~m}$ wide fault zone to the north of Alibag which becomes N-S and $200 \mathrm{~m}$ wide at Uran, and shows close-spaced fracturing, slickensides and iron oxide 
WESTERN FAULT

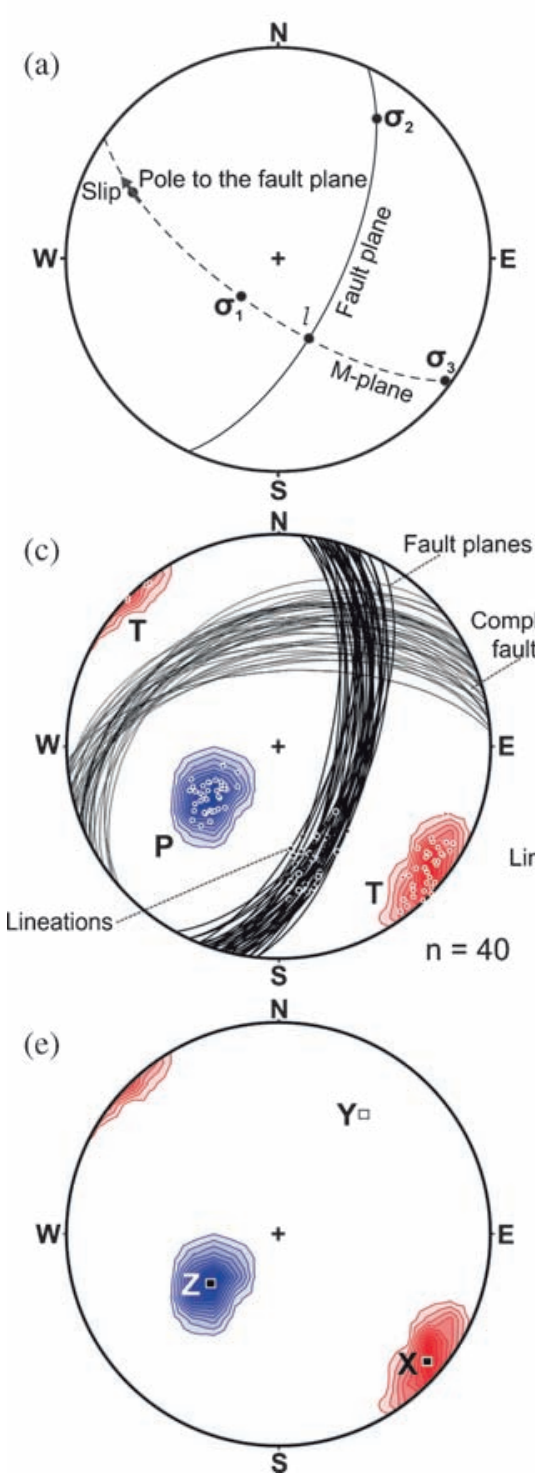

EASTERN FAULT

(b)

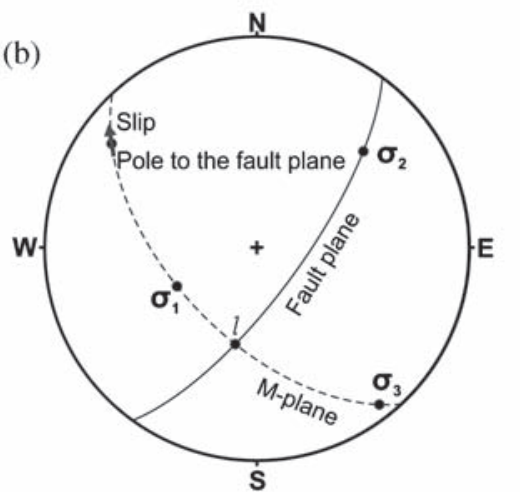

(d)

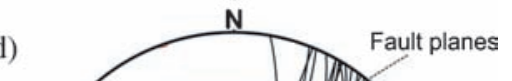

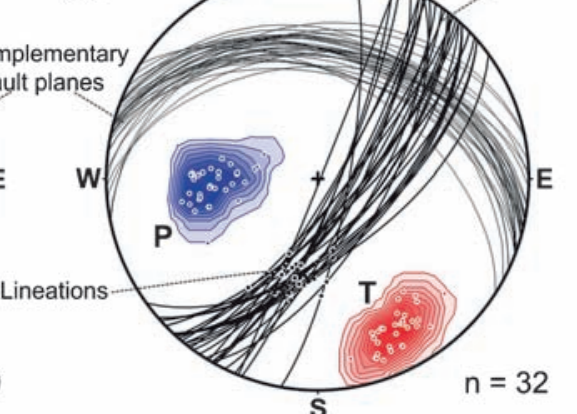

(f)

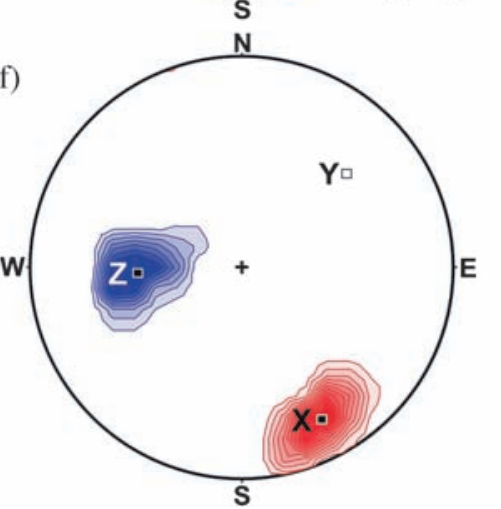

Figure 10. (a, b) Stereographic projection of lineations present on the western and eastern fault planes along with the tangent-lineations (arrows) marked tangential to each M-plane, at the poles to the respective fault planes. The maximum and minimum principal stresses $\sigma_{1}$ and $\sigma_{3}$ are plotted on the M-planes while the intermediate principal stresses $\sigma_{2}$ lie on the fault planes. 'l' indicates the lineations on the fault planes. The plots were prepared using the Stereonet 9 software of Richard Allmendinger (http://www.geo.cornell.edu/geology/faculty/RWA/programs/stereonet.html). (c, d) Plots of the western and eastern fault planes, lineations and the complementary fault planes. Each P- and T-axis bisects these two planes and lies $45^{\circ}$ on either side of each fault plane. The $\mathrm{P}$ - and T-axes have been contoured to represent the overall contractional and extensional fields. (e, f) Plots showing the orientation of the palaeostrain axes X, Y and Z for the western and eastern fault planes, respectively. The intermediate strain axis Y plots at the intersections of the fault planes and their respective complementary planes while the directions of maximum and minimum extension, $\mathrm{X}$ and $\mathrm{Z}$, plot in the middle of the T- and P- fields respectively. The plots in panels (c-f) were prepared using the FaultKin 7 software of Richard Allmendinger (http://www.geo.cornell.edu/geology/faculty/RWA/programs/faultkin.html) (see Marrett and Allmendinger 1990; Allmendinger et al. 2012). Note how, for each fault, the maximum and minimum strain axes (X and Z in figure 10e, f) correspond to the minimum and maximum stress axes $\left(\sigma_{3}\right.$ and $\sigma_{1}$ in figure $10 \mathrm{a}$, b), respectively.

vein networks. At Alibag, the fault plane dips $40^{\circ} \mathrm{E}$, though the relative displacement cannot be determined in the absence of marker horizons. Also, the basalts dip $10^{\circ}$ west at Uran, but adjacent to the fault zone they dip $25^{\circ}$ west or southwest, which led Dessai and Bertrand (1995) to infer block rotations (in an approximately $\mathrm{E}-\mathrm{W}$ plane) adjacent to faults (see their figure 5). The second fault depicted by them is the N-S-trending Nhava-Sheva Fault (figure 2), for which an easterly downthrow (of unspecified magnitude) was identified by Ghodke (1978). The easternmost of the three faults is the N-S-trending Belpada Fault (figure 2), also with fracturing and slickensides, for which 
Ghodke (1978) inferred an easterly downthrow of $60 \mathrm{~m}$.

Dessai and Bertrand (1995) therefore suggested a step-faulting configuration with downthrows systematically to the east for all three faults. The key sections affording these observations have either become destroyed in the massive urbanization the region has experienced, or become inaccessible due to strategic constructions. The faults we describe from Elephanta Island have survived due to lack of such development on the island, though large parts of these faults have been destroyed by quarrying. The Elephanta Island fault zone was not described by Dessai and Bertrand (1995), but it is very likely a northward extension of the AlibagUran fault zone they described. This fault zone thus changes in strike from south to north, from $\mathrm{N} 35^{\circ} \mathrm{E}$ (and $25 \mathrm{~m}$ wide) at Alibag, to $\mathrm{N}-\mathrm{S}$ (and $200 \mathrm{~m}$ wide) at Uran, and again splaying into two distinct faults striking $\mathrm{N} 25^{\circ} \mathrm{E}$ and $\mathrm{N} 36^{\circ} \mathrm{E}$ and $70 \mathrm{~m}$ apart, on Elephanta (figure 2). Even though we do not know the amount of downthrow on either of the two Elephanta faults, we know that both faults dip steeply east-southeast and the downthrows for both were towards the east, with net slip vector towards SSE (for the western fault) and SSW (for the eastern fault) Our observations are therefore consistent with the systematic easterly step-faulting envisaged by Ghodke (1978) and Dessai and Bertrand (1995), with the modifications that (1) the movements along the normal faults were not simply downdip but also obliqueslip, and (2) there were even local block rotations (as at Uran) in planes approximately perpendicular to the faults. Such rotations, resulting in differential tilts between imbricate fault blocks, themselves require faults with listric geometry at depth (Wernicke and Burchfiel 1982; Jackson and McKenzie 1983). Listric faulting with roll-over of hangingwall strata (Hamblin 1965; Gibbs 1984) is a key element of Sheth's (1998) model for the Panvel flexure. The colinearity of the Elephanta Island fault zone with the Alibag-Uran fault zone, and the systematic eastward step-faulting identified for the entire set of subparallel fault zones in this area, suggest that they are all Deccan-age faults and integral elements of the Panvel flexure. The Panvel flexure formed at $62.5 \pm 0.5 \mathrm{Ma}$, during the late stages of Deccan flood basalt volcanism (Sheth and Pande 2014). Therefore, the Elephanta Island fault zone arguably formed at $\sim 62.5 \mathrm{Ma}$ and is not a neotectonic feature.

We briefly note that Srinivasan (2002) has proposed a structural scenario for the western Indian rifted margin, including the region shown in figure 2 and northeast of it, involving progressive westward step-faulting. One of the problems with this scenario is that a major fault proposed by Srinivasan (2002) - the Mahim Fault north of Mumbai - runs southwards right through Uran and Nhava-Sheva, can be identified with the faults described above, and yet large-scale downthrow on this fault to the west is proposed by Srinivasan (2002). This is in direct conflict with the eastward step-faulting we observe and support, as described above.

Sheth et al. (2014) observed numerous subvertical, late-stage tholeiitic dykes with a strong preferred orientation in the Ghatkopar-Powai area of Mumbai, $\sim 18 \mathrm{~km} \mathrm{NNW}$ of Elephanta Island (figure 2). They found that $25 \%$ of the dykes had a N-S strike, 25\% had a NNW-SSE strike, and 50\% had a NNE-SSW strike. Because dykes are preferentially emplaced perpendicular to the $\sigma_{3}$ direction (e.g., Gudmundsson and Marinoni 2002), Sheth et al. (2014) inferred a strongly ESE-WNW (broadly $\mathrm{E}-\mathrm{W})$ extensional tectonic regime from the dyke trends. We note that their inferred ESE-WNW $\sigma_{3}$ direction is completely consistent with the ESE-WNW and gently plunging $\sigma_{3}$ directions determined in the present study for the Elephanta Island faults $\left(03^{\circ} / 126^{\circ}\right.$ for the western fault and $08^{\circ} / 142^{\circ}$ for the eastern fault). This is additional evidence for the late-Deccan age of the Elephanta Island faults.

Some interesting questions remain. For example, all authors (Chandrasekharam 1985; Dessai and Bertrand 1995; Sheth 1998; Srinivasan 2002) have described the western Indian rifted margin as a thinned and block-faulted rifted margin. Receiver function analysis of teleseismic data by Mohan and Ravi Kumar (2004) shows that the continental crust over much of this area has normal thickness. Mohan and Ravi Kumar (2004) computed a 41.3 $\mathrm{km}$ crustal thickness for Koproli near Uran, and a $38.2 \mathrm{~km}$ crustal thickness for Nere a little northeast of Panvel (figure 2). The next step is therefore to understand the structural and tectonic evolution of a piece of continental crust that has suffered significant normal faulting and block tectonics, and even rifting, all the while maintaining a crustal thickness typical of cratonic interiors. This may be possible to explain with the simple shear rifting model of Wernicke (1985), which would also explain the consistently landward dips of the rifted margin faults as observed.

\section{Conclusions}

Elephanta Island in the Mumbai harbour, famous for the ca. mid-6th century AD. Hindu rock-cut caves in Deccan basalt (a UNESCO World Heritage site), is poorly described in the geological literature. Here we report a previously unknown fault zone on the island, comprising two large normal 
faults dipping steeply east-southeast. Both faults show well-developed slickensides, and structural measurements indicate oblique-slip movements on both faults. Three other fault zones have been previously described in the region, to the east and south of Elephanta. These are the Alibag-Uran, Nhava-Sheva and Belpada faults, and we suggest that the Elephanta Island fault zone and the Alibag-Uran fault zone constitute a single fault zone with a moderate fluctuation in strike direction along its length. Previously available data and our new data on these fault zones indicate a progressively easterly step-faulting configuration for the whole system, with the important realization that the individual movements were not simply downdip but also oblique-slip, and locally even rotational as at Uran. These combined results provide valuable insights into the internal architecture of the Panvel flexure, a $150 \mathrm{~km}$ long tectonic megastructure along the western Indian rifted margin. Though extensional block faulting of thinned continental crust is a key element of several models proposed for the Panvel flexure, teleseismic studies have indicated crust of normal thickness (as much as $41.3 \mathrm{~km}$ ) under Uran and other areas. This means that attention should be now focussed on understanding how continental crust can undergo normal faulting, block tectonics and even rifting to form a new ocean basin, while maintaining a thickness typical of continental interiors. The simple shear rifting model of Wernicke (1985) may explain this observation and the consistently landward dips of the faults.

\section{Acknowledgements}

We thank two anonymous referees for detailed and critical reviews which helped us to significantly improve the content and presentation, and $\mathrm{N} \mathrm{V}$ Chalapathi Rao for his editorial handling.

\section{References}

Allmendinger R W, Cardozo N C and Fisher D 2012 Structural geology algorithms: Vectors and tensors; Cambridge University Press, Cambridge, 289p.

Angelier J 1994 Fault slip analysis and paleostress reconstruction; In: Continental deformation (ed.) Hancock P L, Pergamon Press, Oxford, pp. 53-100.

Argles T W 2010 Recording structural information; In: Geological field techniques (ed.) Coe A L, Blackwell Publ., London, pp. 163-191.

Auden J B 1949 Dykes in western India - a discussion of their relationships with the Deccan Traps; Trans. Nat. Acad. Sci. India 3 123-157.

Bhattacharya G C and Yatheesh V 2015 Plate-tectonic evolution of the deep ocean basins adjoining the western continental margin of India - a proposed model for the early opening scenario; In: Petroleum geosciences: Indian contents (ed.) Mukherjee S, Springer, Switzerland, $61 \mathrm{p}$.

Blekinsop T 2002 Deformation microstructures and mechanisms in minerals and rocks; Kluwer Academy Publ., Dordrecht, 105p.

Blanford W T 1867 On the traps and intertrappean beds of western and central India; Geol. Surv. India Memoir 6 $137-162$.

Cheeney R F 1983 Statistical methods in geology; G Allen and Unwin, London, 169p.

Chandrasekharam D 1985 Structure and evolution of the western continental margin of India deduced from seismic, geomagnetic and geochronological studies; Phys. Earth Planet. Inter. 41 186-198.

Collier J S, Sansom V, Ishizuka O, Taylor R N, Minshull T A and Whitmarsh R B 2008 Age of Seychelles-India break-up; Earth Planet. Sci. Lett. 272 264-277.

Cripps J A, Widdowson M, Spicer R A and Jolley D W 2005 Coastal ecosystem responses to late stage Deccan Trap volcanism: The post $\mathrm{K}-\mathrm{T}$ boundary (Danian) palynofacies of Mumbai (Bombay), west India; Palaeogeogr. Palaeoclimatol. Palaeoecol. 216 303-332.

Dessai A G and Bertrand H 1995 The 'Panvel Flexure' along the western Indian continental margin: An extensional fault structure related to Deccan magmatism; Tectonophys. 241 165-178.

Doblas M 1998 Slickenside kinematic indicators; Tectonophys. 295 187-197.

Doblas M, Mahecha V, Hoyos M, Lopez-Ruiz J and Aparicio A 1995 Slickenside kinematic indicators in high and low-angle normal faults in the Alpine Betic Cordilleras southern Spain; In: Geological Society of America Penrose Conference on 'Fine-grained Fault Rocks', Leavenworth, WA.

Duraiswami R A, Bondre N R and Managave S 2008 Morphology of rubbly pahoehoe (simple) flows from the Deccan volcanic province: Implications for style of emplacement; J. Volcanol. Geotherm. Res. 177 822-836.

Faller A M and Soper N J 1979 Palaeomagnetic evidence for the origin of the coastal flexure and dyke swarm in central East Greenland; J. Geol. Soc. London 136 737-744.

Fleuty M J 1974 Slickensides and slickenlines; Geol. Mag. 112 319-322.

Fleuty M J 1987 Slikensides and slikenlines; In: The Encyclopedia of structural geology and plate tectonics (ed.) Seyfert C K, Van Nostrand Reinhold Co., New York, pp. $729-731$.

Fossen H 2010 Structural geology; Cambridge University Press, Cambridge, 463p.

Ghodke S S 1978 Geology of the area around Panvel, Kolaba dist., Maharashtra; Unpubl. PhD thesis, University of Pune.

Gibbs A D 1984 Structural evolution of extensional basin margins; J. Geol. Soc. London $141609-620$.

Groshong R H Jr 2006 3-D Structural geology - a practical guide to quantitative surface and subsurface map interpretation; 2nd edn, Springer (India), New Delhi, 400p.

Gudmundsson A and Marinoni L B 2002 Geometry, emplacement, and arrest of dykes; Annal. Tecto. 13 71-92.

Hamblin W K 1965 Origins of 'reverse drag' on the downthrown side of normal faults; Geol. Soc. Am. Bull. 16 1154-1164.

Hobbs E B, Means W D and Williams P F 1976 An outline of structural geology; John Wiley and Sons, New York, $571 \mathrm{p}$.

Hooper P, Widdowson M and Kelley S 2010 Tectonic setting and timing of the final Deccan flood basalt eruptions; Geology 38 839-842.

Jackson J and McKenzie D 1983 The geometrical evolution of normal fault systems; J. Struct. Geol. 5 471-482. 
Klausen M D 2009 The Lebombo monocline and associated feeder dyke swarm: Diagnostic of a successful and highly volcanic rifted margin?; Tectonophys. 468 42-62.

Kundu B and Matam A 2000 Identification of probable faults in the vicinity of Harnai-Ratnagiri region of the Konkan coast, Maharashtra, India; Curr. Sci. $\mathbf{7 8}$ $1556-1560$.

Marrett R A and Allmendinger R W 1990 Kinematic analysis of fault-slip data; J. Struct. Geol. 12 973-986.

Mohan G and Ravi Kumar M 2004 Seismological constraints on the structure and composition of western Deccan volcanic province from converted phases; Geophys. Res. Lett. 31 L02601.

Mohan G, Surve G and Tiwari P K 2007 Seismic evidences of faulting beneath the Panvel flexure; Curr. Sci. 93 991-996.

Misra A A, Bhattacharya G, Mukherjee S and Bose N 2014 Near N-S paleo-extension in the western Deccan region, India: Does it link strike-slip tectonics with IndiaSeychelles rifting?; Int. J. Earth Sci. 103 1645-1680.

Myers J S 1980 Structure of the coastal dyke swarm and associated plutonic intrusions of East Greenland; Earth Planet. Sci. Lett. 46 407-418.

Nielsen T F D and Brooks C K 1981 The East Greenland rifted continental margin: An examination of the coastal flexure; J. Geol. Soc. London 138 559-568.

Pande K, Sheth H C and Bhutani R $2001{ }^{40}$ Ar- ${ }^{39}$ Ar age of the St. Mary's Islands volcanics, southern India: Record of India-Madagascar breakup on the Indian subcontinent; Earth Planet. Sci. Lett. 193 39-46.

Petit J P and Laville E 1987 Morphology and structures of hydroplastic slickensides in sandstones; In: Deformation of sediments and sedimentary rocks (eds) Jones M E and Preston R M F, Geol. Soc. London Spec. Publ. 29 107121.

Ragan D M 2009 Structural geology: An introduction to geometrical techniques; Cambridge University Press, Cambridge, 602p.

Samant H 1997 A geomorphic analysis of the MumbaiMumbra region, and its applications using a geographic information system; Unpubl. Ph.D. thesis, IIT Bombay, $233 p$.

Sethna S F 1981 Geology around Bombay - some intriguing problems; In: Deccan volcanism (eds) Subbarao K V and Sukheswala R N, Geol. Soc. India Memoir 3 87-92.

Sethna S F 1999 Geology of Mumbai and surrounding areas and its position in the Deccan volcanic stratigraphy, India; J. Geol. Soc. India 53 359-365.

Sheth H C 1998 A reappraisal of the coastal Panvel flexure, Deccan Traps, as a listric-fault-controlled reverse drag structure; Tectonophys. 294 143-149.

Sheth H C and Pande K 2014 Geological and ${ }^{40} \mathrm{Ar} /{ }^{39} \mathrm{Ar}$ age constraints on late-stage Deccan rhyolitic volcanism, inter-volcanic sedimentation, and the Panvel flexure from the Dongri area, Mumbai; In: Flood basalts of Asia (eds) Sheth H C and Vanderkluysen L, J. Asian Earth Sci. 84 $167-175$.

Sheth H C, Ray J S, Senthil Kumar P, Duraiswami R A, Chatterjee R N and Gurav T 2011 Recycling of flow-top breccia crusts into molten interiors of flood basalt lava flows: Field and geochemical evidence from the Deccan Traps; In: Topics in igneous petrology (eds) Ray J, Sen G and Ghosh B, Springer, pp. 161-180.

Sheth H C, Zellmer G F, Demonterova E I, Ivanov A V, Kumar R and Patel R K 2014 The Deccan tholeiite lavas and dykes of Ghatkopar-Powai area, Mumbai, Panvel flexure zone: Geochemistry, stratigraphic status, and tectonic significance; In: Flood basalts of Asia (eds) Sheth $\mathrm{H}$ C and Vanderkluysen L, J. Asian Earth Sci. 84 69-82.

Sheth H, Pal I, Patel V, Samant H and D'Souza J 2017 Breccia-cored columnar rosettes in a rubbly pahoehoe lava flow, Elephanta Island, Deccan Traps, and a model for their origin; Geosci. Front. (in press).

Srinivasan V 2002 Post-Deccan Trap faulting in Raigad and Thane districts of Maharashtra; J. Geol. Soc. India 59 23-31.

Storey M, Mahoney J J, Saunders A D, Duncan R A, Kelley S P and Coffin M F 1995 Timing of hotspot-related volcanism and the breakup of Madagascar and India; Science $267852-855$.

Sukheswala R N and Poldervaart A 1958 Deccan basalts of the Bombay area, India; Geol. Soc. Am. Bull. 69 1475-1494.

Wager L R and Deer W A 1938 A dyke swarm and coastal flexure in East Greenland; Geol. Mag. 79 49-56.

Wernicke B 1985 Uniform-sense normal simple shear of the continental lithosphere; Can. J. Earth Sci. 22 108-125.

Wernicke B and Burchfiel B C 1982 Modes of extensional tectonics; J. Struct. Geol. 4 105-115.

Widdowson M and Mitchell C 1999 Large scale stratigraphical, structural and geomorphological constraints for earthquakes in the southern Deccan Traps: The case of denudationally driven seismicity; In: Deccan volcanic province (ed) Subbarao K V, Geol. Soc. India Memoir 43(1) 425-452.

Wynne A B 1886 On the geology of the island of Bombay; Geol. Soc. India Memoir 2 174-227.

Yamaji A 2007 An introduction to tectonophysics: Theoretical aspects of structural geology; Terrapub, Tokyo, $386 \mathrm{p}$.

Zellmer G F, Sheth H C, Iizuka Y and Lai Y-J 2012 Remobilization of granitoid rocks through mafic recharge: Evidence from basalt-trachyte mingling and hybridization in the Manori-Gorai area, Mumbai, Deccan Traps; Bull. Volcanol. 74 47-66. 